\title{
Modulation of Mast Cell Toll-Like Receptor 3 Expression and Cytokines Release by Histamine
}

\author{
Guogang Xie ${ }^{a}$ Feng Wang ${ }^{b}$ Xia Peng ${ }^{c}$ Yuting Liang ${ }^{c}$ Haiwei Yang ${ }^{b}$ Li Lic $^{c}$ \\ aDepartment of Respiratory Medicine, Shanghai General Hospital, Shanghai JiaoTong University School \\ of Medicine, ${ }^{b}$ Department of Urology, The First Affiliated Hospital of Nanjing Medical University, \\ 'Department of Laboratory Medicine, Shanghai General Hospital, Shanghai Jiao Tong University School \\ of Medicine, China
}

\section{Key Words}

Toll like receptor $• \mathrm{MCP}-1 \cdot \mathrm{IL}-13 \cdot$ Mast cell

\begin{abstract}
Background/Aims: As a major inflammatory molecule released from mast cell activation, histamine has been reported to regulate TLRs expression and cytokine production in inflammatory cells present in the microenvironment. In this study, we determined the ability of histamine to modulate TLRs expression and cytokine production in mast cells. Methods: HMC-1 and P815 cells were exposed to various concentrations of histamine in the presence or absence of histamine antagonist for 2, 6 or $16 \mathrm{~h}$. The effect of histamine on the expression of TLR3 protein and mRNA was analyzed by flow cytometry、RT-PCR and immunofluorescent microscopy. Furthermore, we also examined the effect of histamine on the secretion of MCP1 and IL-13 from mast cells by ELISA. Results: The amplification of TLR3 mRNA and protein expression in mast cells was observed after incubation with histamine, which was accompanied by increasing secretion of IL-13 and MCP-1 via $\mathrm{H} 1$ receptor. The signaling pathways of PI3K/ Akt and Erk1/2/MAPK contributed to these induction effects. Conclusion: These results demonstrate that histamine up-regulates the expression of TLR3 and secretion of IL-13 and MCP-1 in mast cells, thus identifying a new mechanism for the histamine inducing allergic response.

\section{Introduction}

Mast cells have an essential role in allergic diseases, and have shown to be essential in regulating host defense, innate and acquired immunity, homeostatic responses, and immuneregulation [1-4]. Activation of mast cells via cross-linking of membrane bound IgE induces a release of potent mediators including histamine. Besides its pro-inflammatory effect,

G. Xie and F. Wang contributed equally to this work.

Li Li
and Haiwei Yang

KARGER
Department of Laboratory Medicine, Shanghai General Hospital, Shanghai Jiao Tong University School of Medicine, Department of Urology, The First Affiliated Hospital of Nanjing Medical University (China); E-Mail annylish@126.com, haiweiyang@njmu.edu.cn 
histamine exerts other regulatory functions by modulating the activity of T cells, monocytes, macrophages, eosinophils [5] and basophils [6]. In addition, histamine can inhibit further degranulation of mast cells by acting on $\mathrm{H} 4$ receptors [7], which suggests it is insolvent in the feed-back regulation of immunological responses.

Recently, mast cell have also been found essential in the defense against bacteria and viruses via the Toll-like receptors (TLRs), which are a family of receptors that have the ability to recognize a wide variety of pathogen-associated molecular patterns (PAMP) [8-11]. Until now, a total of 10 human TLRs including TLR1-10 and 13 mouse TLRs including TLR1-9 and TLR11-13 have been discovered [8]. Also, there is a research in progress on the ligands and some functional interactions of these receptors. For example, peptidoglycan stimulation of bone marrow-derived mast cells via TLR2 leads to both cytokine release and degranulation [12]. TLR3 can recognize viral double-stranded RNA, which lead to immune responses characterized by the production of type I interferons and proinflammatory cytokines [13]. Moreover, TLR3 enhances eosinophils infiltration in experimental allergic conjunctivitis [14] and contact dermatitis [15].

Since TLRs are known as receptors for micro-organism pathogens that are highly expressed in mast cells, histamine has been reported to regulate TLR expression and cytokine production in inflammatory cells [16-19]; to enhance the secretion of Th2 cytokines such as IL-4, IL-5, IL-10 and IL-13; and to inhibit the production of Th1 cytokines such as IL-2 and IFN- $\gamma[20]$, we anticipated that histamine ought to regulate TLR expression and cytokine production in mast cells, and thus participate in the pathogenies of allergic diseases. In the present study, we found that histamine was able to upregulate expressions of TLR3, and IL13 and MCP-1 released from human and mouse mast cells lines.

\section{Materials and Methods}

\section{Reagents and cells}

HMC-1 cell line was kindly provided by Dr. Zuotao Zhao from the First Hospital, Peking University, Beijing. P815 cell line was purchased from American Type Culture Collection (Manassas, VA, USA). Human and mouse MCP-1 and IL-13 ELISA kits were bought from R\&D (Minneapolis, MN). Tissue culture reagents including Dulbecco's modified Eagle's medium (DMEM), RPMI 1640 media, HEPES and Fetal bovine serum (FBS) were obtained from GibcoBRL (Carlsbad, CA, USA). Histamine, terfendine and cimetidine were purchased from Sigma-Aldrich (St. Louis, MO, USA). TRIzol Reagent and SYBR Green I Stain were from Invitrogen (Carlsbad, CA, USA). ExScript ${ }^{\mathrm{TM}}$ RT reagent kit and SYBR ${ }^{\circledR}$ Premix Ex Taq ${ }^{\mathrm{TM}}$ (perfect real time) were from TaKaRa (DaLian, China). FITC-conjugated rat monoclonal antibody against mouse TLR3, PE-conjugated mouse monoclonal antibody against human TLR3, PE-conjugated mouse isotype control and FITC-conjugated rat isotype control were from Immugenex Corp (Los Angeles, CA, USA). Monoclonal antibodies that detect activating phosphorylations or unphosphorylations of Akt (Ser473), and ERK-1/2 (Thr202/Tyr204) were from Cell Signaling Technology (Beverly, ME, USA). LY294002, U0126, SB203580 and AG490 were purchased from Promega (Madison, WI, USA). Poly (I:C) was from the Invivogen (San Diego, CA, USA). Most of other reagents such as salt and buffer components were analytical grade and were obtained from Sigma-Aldrich (St. Louis, MO, USA).

\section{Cell culture}

All cells were cultured in $75-\mathrm{cm}^{2}$ tissue culture flasks in a humidified atmosphere containing $5 \% \mathrm{CO}_{2} / 95 \%$ air at $37^{\circ} \mathrm{C}$. HMC-1 cells were maintained in RPMI 1640 media supplemented with $10 \mathrm{mM}$ HEPES, gentamycin $50 \mu \mathrm{g} / \mathrm{ml}, 2 \mathrm{mM}$ L-glutamine, $100 \mathrm{U} / \mathrm{ml}$ penicillin, $100 \mu \mathrm{g} / \mathrm{ml}$ streptomycin and $10 \%$ heat inactivated fetal bovine serum; P815 cells were cultured with ATCC complete growth medium including DMEM supplemented with $4 \mathrm{mM}$ L-glutamine, $1.5 \mathrm{mg} / \mathrm{ml}$ sodium bicarbonate, $4.5 \mathrm{mg} / \mathrm{ml}$ glucose, $10 \%$ FBS, $100 \mathrm{U} / \mathrm{ml}$ penicillin and $100 \mu \mathrm{g} / \mathrm{ml}$ streptomycin.

Cell challenge

For the challenge experiments, mast cell lines HMC-1 and P815 at $1 \times 10^{6}$ cells $/ \mathrm{ml}$ concentration were transferred into 6-well plastic culture plates, cultured with the serum-free basal medium for $16 \mathrm{~h}$ and 


\section{Cellular Physiology Cell Physiol Biochem 2018;46:2401-2411 \\ \begin{tabular}{l|l} 
and Biochemistry Published online:May 09, 2018 & $\begin{array}{l}\text { Do } 2018 \text { The Author(s). Published by S. Karger AG, Basel } \\
\text { www.karger.com/cpb }\end{array}$ \\
\hline
\end{tabular}}

Xie et al.: Histamine Up-Regulates TLR3 Expression in Mcs

washed twice before challenge. Cells were then exposed to various concentrations of histamine $(0.01-10.0$ $\mu \mathrm{g} / \mathrm{ml}$ ) for 2, 6 or $16 \mathrm{~h}$. After centrifugation, culture supernatants were collected and stored at $-80^{\square} \mathrm{C}$ until use, and cells were harvested for immunofluorescence and real time PCR.

For certain experiments, cells were preincubated with $1.0 \mu \mathrm{g} / \mathrm{ml}$ of terfenadine or $10 \mu \mathrm{g} / \mathrm{ml}$ cimetidine for $1 \mathrm{~h}$ before addition of histamine. At $6 \mathrm{~h}$ or $16 \mathrm{~h}$ following incubation, the culture plates were centrifuged at $450 \mathrm{~g}$ for $10 \mathrm{~min}$ at $25^{\circ} \mathrm{C}$. The cells were then harvested for immunofluorescence and real time PCR. The culture supernatants were collected and stored at $-80^{\circ} \mathrm{C}$ for further use.

To determine if histamine affects poly (I:C) induced MCP-1 and IL-13 release, cells were preincubated with $0.1 \mu \mathrm{g} / \mathrm{ml}$ of histamine for $16 \mathrm{~h}$ before adding $25 \mu \mathrm{g} / \mathrm{ml}$ poly (I:C) for $16 \mathrm{~h}$. The culture supernatants were collected and stored at $-80^{\circ} \mathrm{C}$ for further use.

For cell signaling experiments, cultured cells at a density of $1.0 \times 10^{6}$ cells $/ \mathrm{ml}$ were washed twice with the serum-free basal medium, and then were treated with the inhibitors of cell signaling pathways, including U0126 (5 $\mu \mathrm{M})$, SB203580 $(20 \mu \mathrm{M})$, LY294002 $(20 \mu \mathrm{M})$ and AG490 $(40 \mu \mathrm{M})$ for 30 min before being challenged with histamine $(10 \mu \mathrm{g} / \mathrm{ml})$ for $30 \mathrm{~min}, 2 \mathrm{~h}$, and $6 \mathrm{~h}$. The culture supernatants were then collected and stored at $-80^{\circ} \mathrm{C}$, and cells were collected for immunofluorescence analysis or ELISA and cell signal analysis. The concentrations of inhibitors were chosen according to previous study [18].

\section{Enzyme linked immunosorbent assay (ELISA) for cytokine secretion}

MCP-1 and IL-13 were measured using ELISA kits according to the manufacturer's instruction.

\section{Flow cytometry analysis and immunofluorescence cell staining}

HMC-1 and P815 cells were pelleted by centrifugation at $450 \mathrm{~g}$ for $10 \mathrm{~min}$, and then fixed in $2 \%$ paraformaldehyde at $4{ }^{\circ} \mathrm{C}$ for $30 \mathrm{~min}$. After washing, the cells were resuspended in phosphate-buffered saline (PBS) and incubated with FITC-conjugated rat monoclonal antibody against mouse TLR3, PEconjugated mouse monoclonal antibody against human TLR3, PE-conjugated mouse or FITC-conjugated rat isotype control at $37^{\circ} \mathrm{C}$ for $1 \mathrm{~h}$. After washing, cells were analyzed on a FACS Aria flow cytometer with FACSDiva software (BD Biosciences) on a Zeiss 5 LIVE confocal laser scanning microscope (Zeiss, German).

\section{Examination of $m R N A$ expression of TLR3}

Total RNA was isolated from HMC-1 and P815 cells, using TRIzol reagent and treated with RNase-free DNase I to remove contaminated DNA according to the manufacturer's protocol. After the first-strand cDNA was obtained by incubating RNA with oligo-dT primers, $1 \mu \mathrm{l}$ of each cDNA sample (corresponding to 100 ng total RNA) was used for quantitative real-time PCR. Quantitative real-time PCR assay of transcripts was performed in an ABI StepOne Plus Sequence Detection System Thermal cycler (Applied Biosystems, Foster City, CA) with SYBR ${ }^{\circledR}$ Premix Ex Taq ${ }^{\text {TM }}$ PCR Kit. Each reaction contains $12.5 \mu$ of $2 \times$ SYBR green Master Mix, $1 \mu \mathrm{l}$ of $10 \mu \mathrm{M}$ of primers, $1 \mu \mathrm{l}$ of the cDNA, to a total volume of $25 \mu \mathrm{l}$. The thermal cycling conditions included an initial denaturation step at $52{ }^{\circ} \mathrm{C}$ for $2 \mathrm{~min}, 95{ }^{\circ} \mathrm{C}$ for $10 \mathrm{~min}, 40$ cycles at $95{ }^{\circ} \mathrm{C}$ for $15 \mathrm{~s}$, at gradient annealing temperatures for $30 \mathrm{~s}$. At the end of the PCR cycles, specificities of the amplification products were controlled by dissociation curve analysis. mRNA expression in each sample was finally determined after correction with $\beta$-actin expression. The gene specific threshold cycle (Ct) for each sample was corrected by subtracting the $\mathrm{Ct}$ for the housekeeping gene $\beta$-actin $(\Delta \mathrm{Ct})$. Untreated controls were chosen as the reference samples, and the $\Delta \mathrm{Ct}$ for all experimental samples were subtracted by the $\Delta \mathrm{Ct}$ for the control samples $(\Delta \Delta \mathrm{Ct})$. The magnitude change of test gene mRNA was expressed as $2^{-\Delta \Delta \mathrm{Ct}}$. Each measurement of a sample was conducted in duplicate.

\section{Immunoblotting}

After cells were stimulated with histamine (or medium alone) for $0.5 \mathrm{~h}, 2 \mathrm{~h}, 6 \mathrm{~h}$ and $16 \mathrm{~h}$, cells were washed twice with ice-cold PBS and then lysed for $30 \mathrm{~min}$ in $0.1 \mathrm{ml}$ lysis buffer: $20 \mathrm{mM}$ HEPES, pH 7.3, 1 $\%$ Triton X-100, $10 \%$ glycerol, $12.5 \mathrm{mM}$ sodium pyrophosphate, $10 \mathrm{mM}$ sodium orthovanadate, $50 \mathrm{mM}$ sodium fluoride, $1 \mathrm{mM}$ phenylmethylsulfonyl fluoride, $30 \mu \mathrm{g} / \mathrm{ml}$ leupeptin, $30 \mu \mathrm{g} / \mathrm{ml}$ aprotinin, and $25 \mathrm{mM}$ pnitrophenyl phosphate. Cell debris was removed by centrifugation of the lysate at 13, $000 \mathrm{~g}$ for $10 \mathrm{~min}$. The supernatants were mixed with equal volumes of $5 \times$ sodium dodecyl sulphate sample buffer and heated to $100{ }^{\square} \mathrm{C}$ for $10 \mathrm{~min}$. An equal volume of sample was then fractionated by SDS-PAGE on a $10 \%$ acrylamide gel and transferred onto a polyvinylidene difluoride (PVDF) membrane with a Bio-Rad semidry transfer 


\section{Cellular Physiology Cell Physiol Biochem 2018;46:2401-2411 and Biochemistry Published online: May 09, $2018 \quad \begin{aligned} & \text { DOI: 10.1159/000489646 } 2018 \text { The Author(s). Published by S. Karger AG, Basel } \\ & \text { www.karger.com/cpb }\end{aligned}$ \\ Xie et al.: Histamine Up-Regulates TLR3 Expression in Mcs}

system, according to the manufacturer's instructions. After blocking non-specific binging sites with $5 \%$ BSA in TBS/Tween for $1 \mathrm{~h}$, membranes were probed with anti-Akt (Ser473), anti-ERK-1/2 (Thr202/Tyr204) or anti-phospho-antibodies overnight followed by incubated with HRP-conjugated secondary antibodies. Immunoreactive bands were visualized using enhanced chemiluminescence reagents (Pierce, Rockford, IL) according to the manufacturer's protocol. Densitometry analysis of immunoblots was carried out using ScionImage software. The relative levels of phospho-Akt (Ser473) or phospho-ERK-1/2 (Thr202/Tyr204) were expressed as the ratio to Akt (Ser473) or ERK-1/2 (Thr202/Tyr204).

\section{Statistical analysis}

Data were expressed as mean \pm SEM for four independent experiments. Where analysis of variance indicated significant differences between groups with ANOVA, for the preplanned comparisons of interest, Student's t-test was applied utilizing the SPSS19.0 version. $P<0.05$ was considered statistically significant.

\section{Results}

\section{Expression of TLR3 in mast cells}

RT-PCR, FACS analysis and immunofluorescent cell staining were employed to examine the expression of TLR3 in HMC-1 and P815 cells. The results showed that both human and mouse mast cells express TLR3 mRNA (Fig. 1A) and protein (Fig. 1B and 1C).

\section{Influence of histamine on the expression of TLR3 mRNA in mast cells}

Quantitative real-time PCR results showed that histamine induced the up-regulation of expression of TLR3 mRNA. Histamine at the concentrations of $0.1,1.0$ and $10 \mu \mathrm{g} / \mathrm{ml}$ induced a dose-dependent upregulation of TLR3 mRNA expression following a $6 \mathrm{~h}$ incubation period. The maximum induced expression of TLR3 mRNA was 5.1 and 6.0 fold over baseline control in HMC-1 (Fig. 2A) and P815 (Fig. 2B) cells, respectively.

Furthermore, the time course study showed that upregulated TLR3 mRNA expression was observed at $2 \mathrm{~h}$ and reached almost baseline level at $6 \mathrm{~h}$ following incubation, both in HMC-1 (Fig. 2A) and P815 (Fig. 2B) cells.

Fig. 1. Analysis of the expression of TLR3 in P815 and HMC-1 cells by RT-PCR (A), flow cytometry (B) and immunofluorescent microscopy (C). (A) The gene product of TLR3 was separated in $1.5 \%$ agarose gel, stained with SYBR Green I Nucleic Acid Gel Stain and photographed under ultraviolet light. (B) P815 cells incubated with FITCconjugated rat anti-mouse TLR3 monoclonal antibody and HMC-1 cells incubated with PE-conjugated rat antihuman TLR3 monoclonal antibody were analyzed on a FACS Arial flow

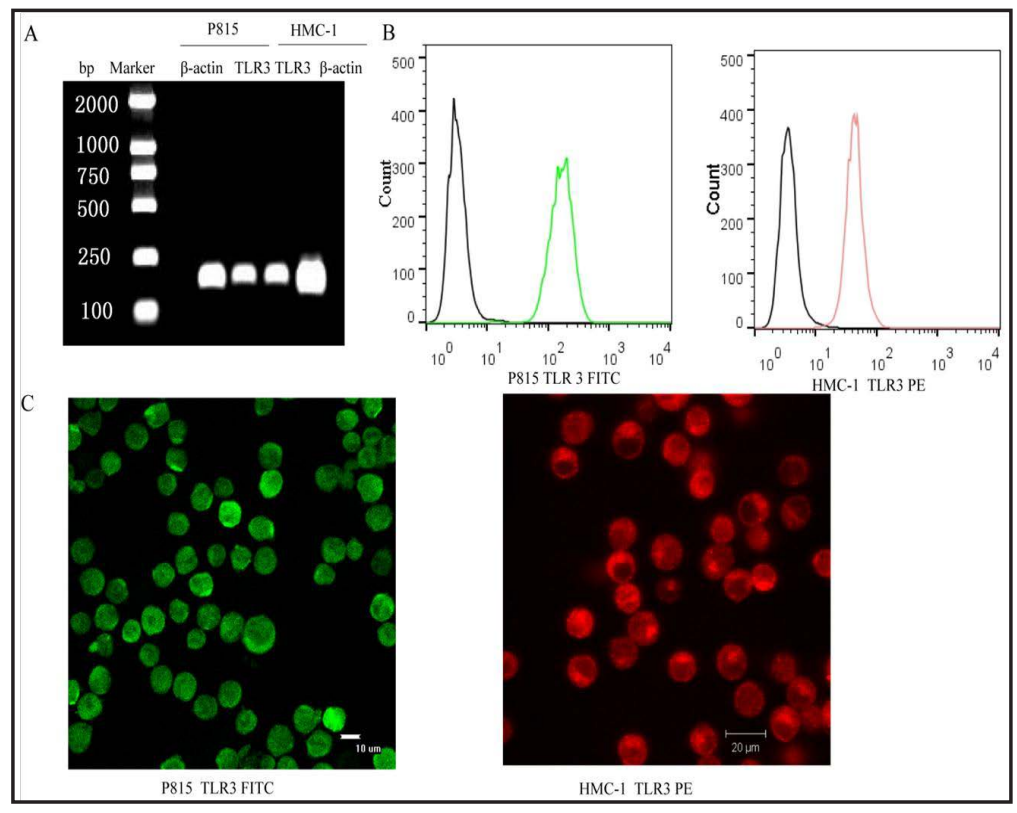
cytometer with CellDevia software. (C) Cells were treated with the above-mentioned procedures and immunofluorescent microscopy was performed with a Zeiss 5 LIVE confocal laser scanning microscope. Cells in green are FITC positive stained P815 cells. Cells in red are PE positive stained HMC-1 cells. 
Fig. 2. Histamine induced the expression of TLR3 mRNA in HMC-1 and P815 cells. Mast cells were incubated with various concentrations of histamine at $37^{\circ} \mathrm{C}$ for 2,6 and $16 \mathrm{~h}$, respectively. The expression of TLR3 mRNA in HMC-1cells (A) or P815 cells (B) was determined by quantitative real-time PCR.

\section{Influence of histamine on expression of} TLR3 on mast cells

In HMC-1 cells, induced upregulation of TLR3 was observed after $6 \mathrm{~h}$ incubation with 1.0 and $10 \mu \mathrm{g} / \mathrm{ml}$ histamine, and after $16 \mathrm{~h}$ incubation with $0.1,1.0$ and $10 \mu \mathrm{g} / \mathrm{ml}$ histamine (Fig. 3A). In P815 cells, induced upregulation of TLR3 was found after $6 \mathrm{~h}$ incubation with $10 \mu \mathrm{g} / \mathrm{ml}$ histamine, and after $16 \mathrm{~h}$ incubation with $0.1,1.0$ and 10 $\mu \mathrm{g} / \mathrm{ml}$ histamine (Fig. 3B). Approximately, 2-fold upregulated expression of TLR3 was observed when HMC-1 and P815 cells were incubated with $10 \mu \mathrm{g} / \mathrm{ml}$ of histamine for $16 \mathrm{~h}$.

Inhibition of histamine-induced expression of TLR3 by anti-histamine drugs

After a $1 \mathrm{~h}$ incubation period, histamine $\mathrm{H} 1$ receptor antagonist terfenadine at 1.0 $\mu \mathrm{g} / \mathrm{ml}$ was able to block histamine induced upregulation of TLR3 expression in HMC1 and P815 cells. The results showed that terfenadine at $1.0 \mu \mathrm{g} / \mathrm{ml}$ could block histamine upregulated of TLR3 mRNA expression in mast cells (Fig. 4A). Flow cytometry analysis also showed that terfenadine reduced histamine stimulated upregulation of TLR3 expression by 61 $\%$ and $82.9 \%$ in HMC- 1 and P815 cells, respectively (Fig. 4B).

However, histamine $\mathrm{H} 2$ receptor antagonist cimenidine had low effect on blocking histamine induced TLR3 upregulation expression (Fig. 4).

Effect of histamine on MCP-1 and IL-13 secretion from mast cells

It was found that histamine at 1.0 and 10 $\mu \mathrm{g} / \mathrm{ml}$ induced a concentration dependent secretion of IL-13 and MCP-1 release from mast cells following $16 \mathrm{~h}$ incubation period. Approximately up to 2.2 and 2.6 fold of IL13 releases were achieved when HMC-1 and P815 cells were incubated with $10 \mu \mathrm{g} /$
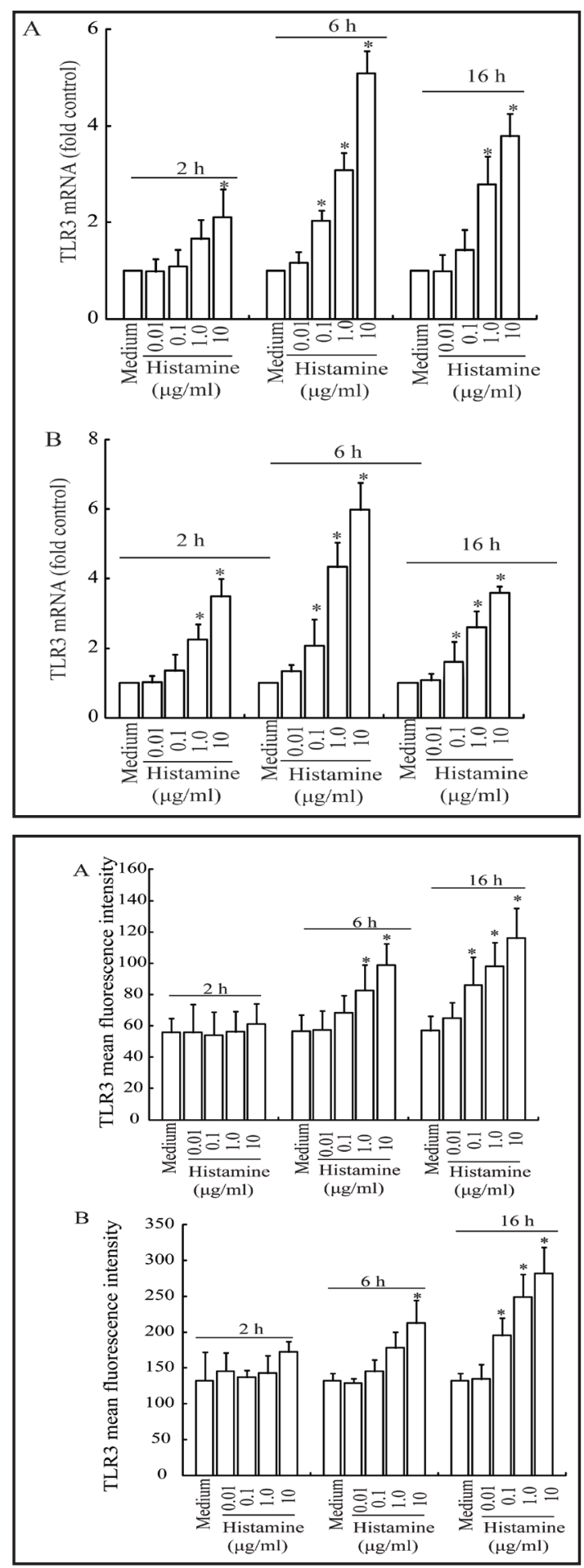

Fig. 3. Histamine induced the expression of TLR3 protein in HMC-1 and P815 cells. Mast cells were incubated with various concentrations of histamine at $37^{\circ} \mathrm{C}$ for 2,6 and $16 \mathrm{~h}$, respectively. The expression of TLR3 protein in HMC-1cells (A) or P815 cells (B) was determined by flow cytometry analysis. ${ }^{*} \mathrm{P}<0.05$ compared with the response to the corresponding medium alone control. 
Fig. 4. Inhibition of histamineinduced expression of TLR3 by anti-histamine drugs. Cells were preincubated with terfenadine at $(1 \mu \mathrm{g} / \mathrm{ml})$ and cimenidine $(10 \mu \mathrm{g} /$ $\mathrm{ml}$ ) for $1 \mathrm{~h}$ before histamine (10 $\mu \mathrm{g} / \mathrm{ml}$ ) being added at $37^{\circ} \mathrm{C}$ for 6 h. The expression of TLR3 mRNA (A) and protein (B) in HMC-1cells and P815 cells was determined by quantitative real-time PCR and flow cytometry analysis, respectively. Cells were treated with the above-mentioned procedures and immunofluorescent microscopy was performed with a Zeiss 5 LIVE confocal laser scanning microscope. Cells in green are FITC positive stained P815 cells (C). Cells in red are PE positive stained HMC-1 cells (D). Values shown are mean \pm

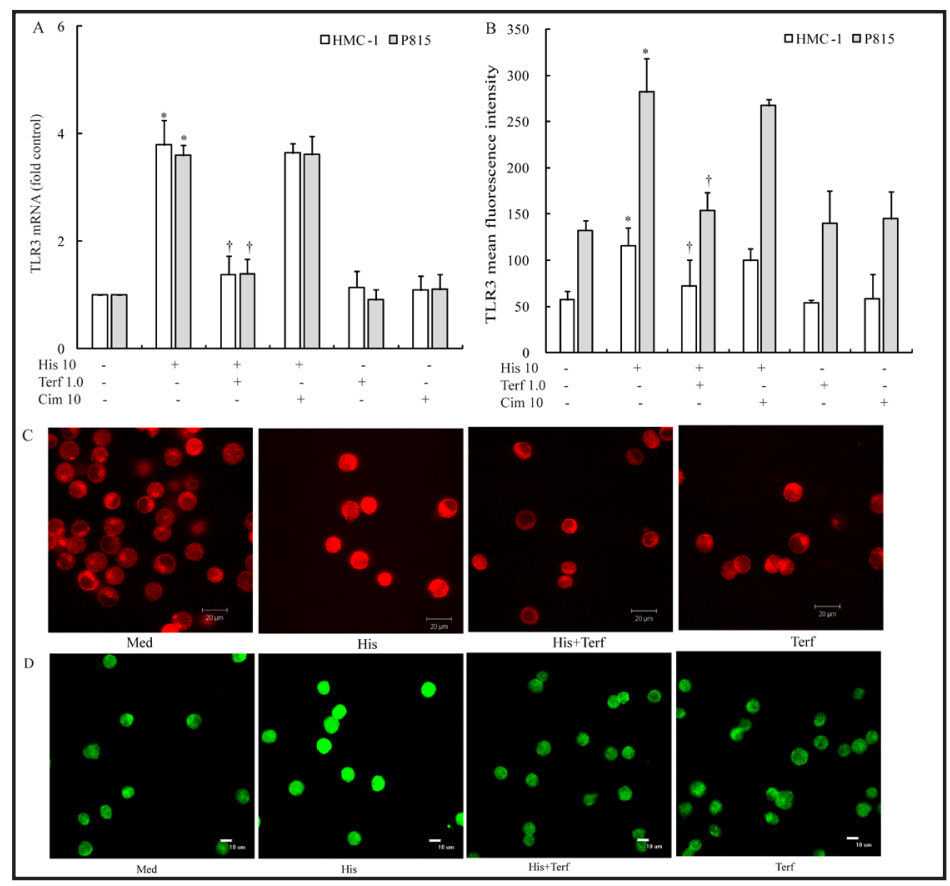
SE for four separate experiments performed in duplicate. ${ }^{*} \mathrm{P}<0.05$ compared with the response to medium alone control. $\uparrow \mathrm{P}<0.05$ compared with the response to corresponding uninhibited control.

Fig. 5. Effect of histamine on MCP-1 and IL-13 secretion from mast cells. Cells were incubated with various concentrations of histamine $(\mu \mathrm{g} / \mathrm{ml})$ with or without terfenadine $(1 \mu \mathrm{g} / \mathrm{ml})$ or poly (I:C) $(25 \mu \mathrm{g} /$ $\mathrm{ml})$ at $37^{\circ} \mathrm{C}$ for $16 \mathrm{~h}$. The secretion of MCP-1 and IL-13 was determined by ELISA. A: IL-13 secretion in HMC-1 cell; B: IL13 secretion in P815 cell; C: MCP-1 secretion in HMC-1 cell; D: MCP-1 secretion in P815 cell. Values shown are mean \pm SE for four separate experiments performed in duplicate. * $\mathrm{P}<0.05$ compared with the response to corresponding medium alone control. $\uparrow \mathrm{P}<0.05$ compared with the response to the corresponding uninhibited control.

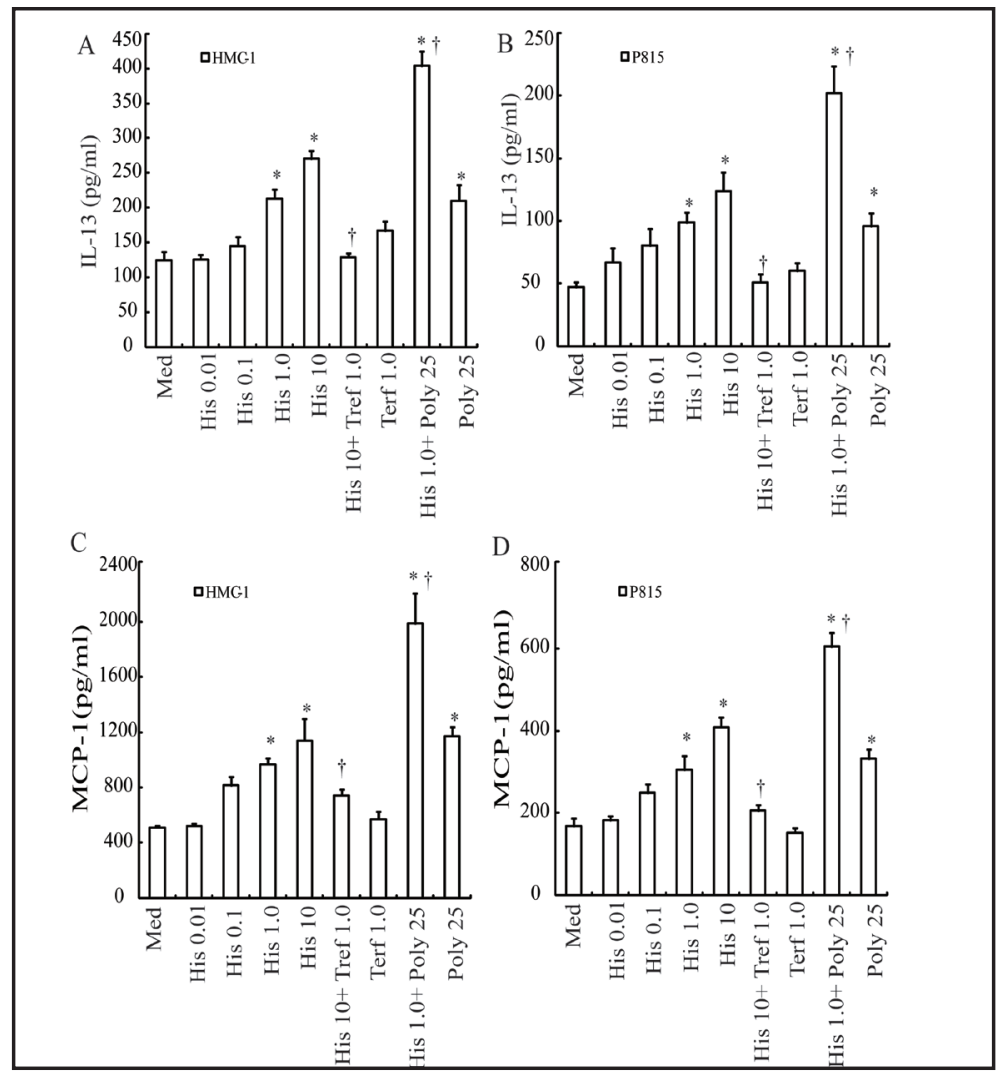

$\mathrm{ml}$ of histamine (Fig. 5A and 5B). After $1 \mathrm{~h}$ incubation period, terfenadine was able to block histamine induced IL-13 secretion (Fig. 5A and 5B). Similarly, histamine at $10 \mu \mathrm{g} / \mathrm{ml}$ induced 
Fig. 6. Effect of LY294002 (LY), U0124 (U0) on histamine induced IL-13 (A, B) and MCP-1 (C, D) secretion and up-regulation of TLR3 expression (E, F) in HMC-1(A, C, E) and P815 cells (B, D, F). Cells were preincubated with LY $(20 \mu \mathrm{M})$, U0124 $(5 \mu \mathrm{M}), \mathrm{U} 0126(5 \mu \mathrm{M})$ or PD $(50 \mu \mathrm{M})$, respectively for $30 \mathrm{~min}$ before histamine $(10 \mu \mathrm{g} / \mathrm{ml})$ being added at $37^{\circ} \mathrm{C}$ for $6 \mathrm{~h}$ (for TLR3 protein) or $16 \mathrm{~h}$ (for MCP-1 and IL-13 secretion). The secretion of MCP-1 and IL-13 was determined by ELISA. The expression of TLR3 protein was determined by flow cytometry analysis. Values shown are mean \pm SE for four separate experiments performed in duplicate. ${ }^{*} \mathrm{P}<0.05$ compared with the response to medium alone control. $\dagger \mathrm{P}<0.05$ compared with the response to corresponding uninhibited control.

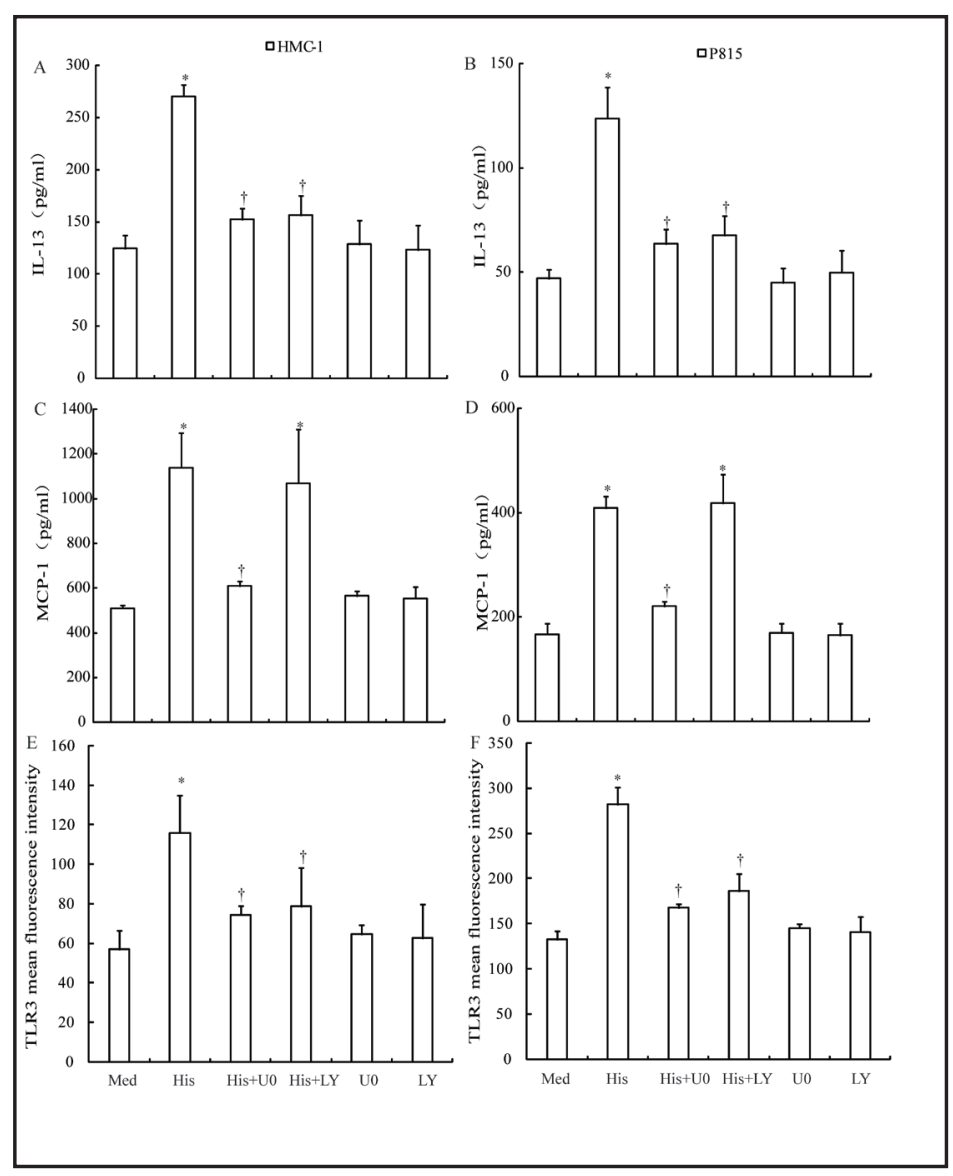

approximately 3.0 and 2.4 fold of MCP-1 releases in HMC- 1 and P815 cells (Fig. 5C and 5D). After $1 \mathrm{~h}$ incubation period, terfenadine was able to block histamine induced MCP-1 and IL13 secretion (Fig. 5C and 5D).

However, histamine $\mathrm{H} 2$ receptor antagonist cimenidine had low effect on blocking histamine induced MCP-1 and IL-13 secretion (data not shown).

To determine the effect of synthetic dsRNA analogue poly (I:C) stimulation on MCP-1 and IL-13 release after histamine challenge, mast cells were preincubated with $0.1 \mu \mathrm{g} / \mathrm{ml}$ of histamine for $16 \mathrm{~h}$ before adding $25 \mu \mathrm{g} / \mathrm{ml}$ poly (I:C) for $16 \mathrm{~h}$. The results showed that histamine was able to enhance the response of HMC-1 and P815 mast cells to poly (I:C) (Fig. 5).

Effect of cell signaling inhibitors on histamine induced release of MCP-1 and IL-13 and expression of TLR3

We employed LY294002 (PI3K/Akt inhibitor), U0126 (a selective inhibitor of MEK1/2 and thus a MAPK pathway inhibitor), SB203580 (a selective inhibitor of p38 MAPK), and AG490 (a JAK/STAT3 pathway inhibitor) to further investigate the potential histamine signaling pathways in HMC-1 and P815 cells.

U0126 and LY294002 diminished histamine induced secretion of IL-13 released by $81 \%$, $78.5 \%$ from HMC-1 cells (Fig. 6A) and 78.3 \%,73.1\% from P815 cells (Fig. 6B), respectively, when they were pre-incubated with the cells for $30 \mathrm{~min}$, indicating that reduction of IL-13 released by histamine occurs through activation of PI3K/Akt and Erk1/2/ MAPK signaling pathways. However, U0126, not LY294002, diminished histamine induced secretion of MCP1 released both in HMC-1 and P815 cells (Fig. 6C and 6D), indicating that reduction of MCP-1 released by histamine occurred through activation of Erk1/2/ MAPK signaling pathways. In contrast, SB203580 and AG490 had little influence on histamine induced reduction of IL-13 
Fig. 7. Influence of histamine on phosphorylation of $\operatorname{ErK}(\mathrm{A})$ and Akt (B) in HMC-1 and P815 cells by Western blot. U0126 (U0,5 $\mu \mathrm{M})$ and LY294002 (LY, $20 \mu \mathrm{M})$ were preincubated with HMC-1 and $\mathrm{P} 815$ cells at $37^{\circ} \mathrm{C}$ for $30 \mathrm{~min}$ before $10 \mu \mathrm{g} / \mathrm{ml}$ of histamine being added for $2 \mathrm{~h}$. The relative levels of phospho-ERK1/2 and phospho-PI3K were expressed as the ratio to GAPDH, an internal control (housekeeping protein), respectively. The values shown are mean \pm SD for four separate experiments. ${ }^{*} \mathrm{P}<0.05$ compared with the response to medium alone. $\dagger \mathrm{P}<0.05$ compared with the response to histamine alone.

and MCP-1 release (data not shown). All tested inhibitors did not significantly affect basal IL-13 and MCP-1 release.

Similarly, U0126 and LY294002 also eliminated histamine induced upregulation of TLR3

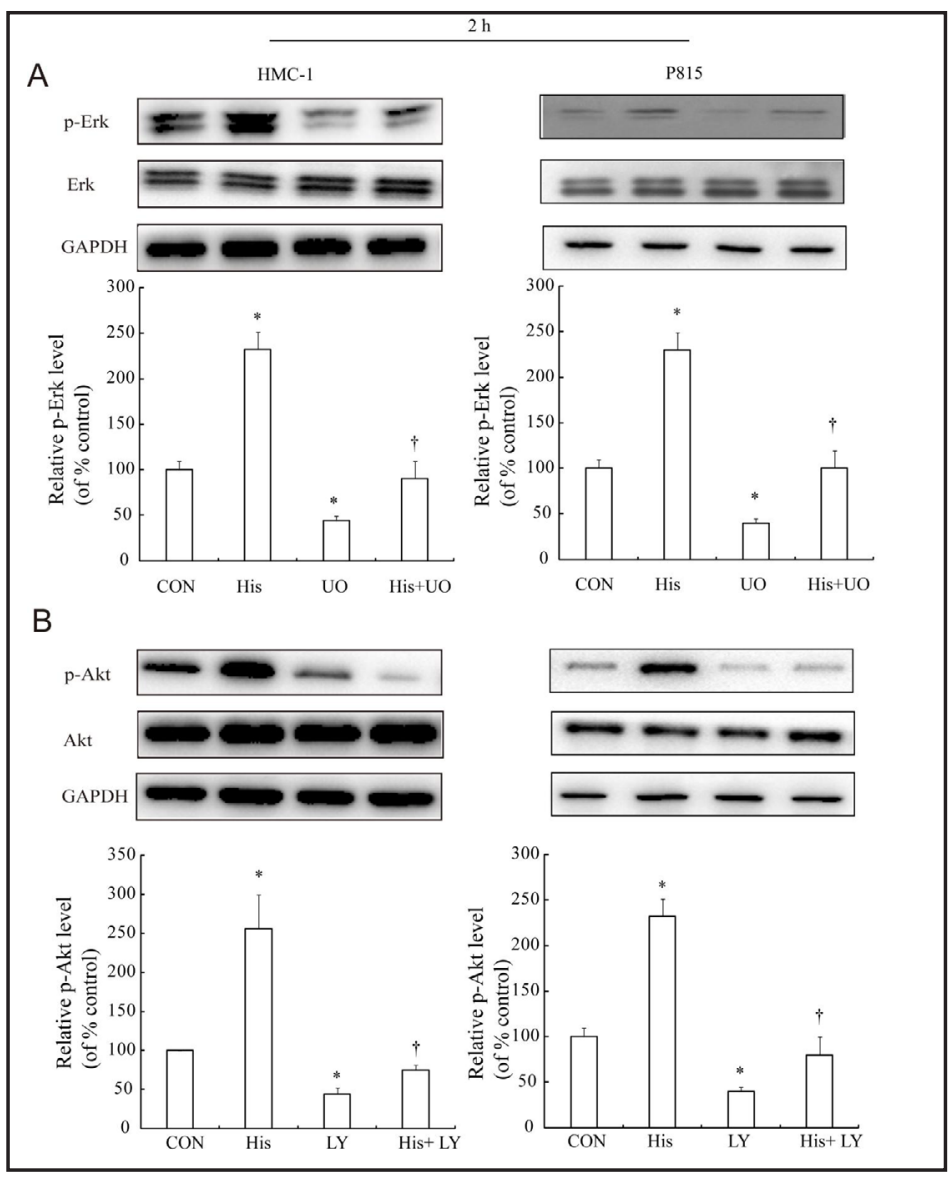
expression up to $70.3 \%, 76.5 \%$ in HMC-1 cells (Fig. 6E), and 63.2 \%, 64.2 \% in P815 cells (Fig. 6F), respectively. All tested inhibitors did not significantly affect basal TLR3 expression in P815 cells.

Inhibition of histamine induced phosphorylation of ERK and PI3K by signaling inhibitors

U0126inhibited approximately up to 50 and $46.7 \%$ of histamine induced phosphorylation of ERK in HMC-1 and P815 cells, respectively at $2 \mathrm{~h}$ following incubation (Fig. 7A). LY294002 diminished histamine induced phosphorylation of Akt by approximately $76.2 \%$ and $50 \%$ in HMC-1 and P815 cells at 2 h following incubation (Fig. 7B). U0126 and LY294002 also inhibited basal phosphorylation of ERK (Fig. 7A) and Akt (Fig. 7B) at $2 \mathrm{~h}$ following incubation.

\section{Discussion}

In the present study, we identified for the first time that histamine, a main component released from mast cells after activation, is able to upregulate the expression of TLR3, and to provoke MCP-1 and IL-13 release from human and mouse mast cells.

Although mast cells are best known for their role in allergic diseases, a series of evidence have highlighted the important roles these cells have in the protection against infection. Members of the TLR superfamily have been the most prominent in performing this function. As the main TLR related to the viral recognition, TLR3 have shown the ability to respond to viral RNAs of selected species, thus leading to production of many cytokines that are critical for regulation of many immunological functions [13]. It has been documented that TLR3 transcript is found in LAD, HMC-1, and P815 cell lines, as well as in BMMCs, HCMCs and mature tissue mast cells [8]. In the present study, we also confirmed that both human mast

\section{KARGER}




\section{Cellular Physiology Cell Physiol Biochem 2018;46:2401-2411 \\ and Biochemistry Published online: May 09, $2018 \quad \begin{aligned} & \text { DOI: 10.1159/000489646 } 2018 \text { The Author(s). Published by S. Karger AG, Basel } \\ & \text { www.karger.com/cpb }\end{aligned}$}

Xie et al.: Histamine Up-Regulates TLR3 Expression in Mcs

cell line (HMC-1) and mouse mast cell lines (P815) expressed TLR3 in mRNA and protein levels.

As the main component released from mast cell activation, histamine has been comprehensively studied as an inflammatory mediator that acts in vascular dilation, smooth muscle contraction, and gastric acid secretion. Nevertheless, little is known about the effect the histamine has on mast cells themselves. Our results demonstrated that histamine could induce upregulation of TLR3 mRNA and protein expression both in HMC-1, and P815 cell lines. LY294002, a PI3K/Akt inhibitor and U0126, a selective inhibitor of MEK1/2 could eliminate histamine induced upregulation of TLR3 expression in HMC-1 and P815 mast cells, respectively, which implies that upregulation of TLR3 expression by histamine occurs through activation of PI3K/Akt [21] and Erk1/2/ MAPK signaling pathways [22]. Moreover, histamine $\mathrm{H} 1$ receptor antagonist terfenadine was able to block histamine induced upregulation of TLR3 mRNA and protein expression in HMC-1 and P815 mast cell. However, histamine $\mathrm{H} 2$ receptor antagonist cimenidine had little effect on blocking the expression of histamine induced TLR3 upregulation. It implied that histamine induced upregulation of TLR3 expression in mast cells was conducted by the $\mathrm{H} 1$ receptor, as opposed to $\mathrm{H} 2$ receptor. The same phenomenon was found in pulmonary epithelial cells. Histamine could upregulate the TLR3 expression in A549 and NCI-H292 cells by H1 receptor [18].

Mast cell secreted cytokines have a pivotal role in the pathogenesis of allergic disease and inflammation [23, 24]. Interleukin-13 (IL-13) and monocyte chemoattractant protein 1 (MCP-1) are two cytokines among those produced by human and mouse mast cells. IL13 is emerging as an important mediator in the development of Th2 cell responses, which can induce IgE secretion from activated human B cells [25]. MCP-1 has a significant role in allergic responses because of its ability to induce mast cell activation and leukotriene C4 release into the airways through its receptor CCR2, which directly induces airway hyperresponsiveness [26]. Our results revealed that histamine could induce the secretion of IL13 and MCP-1 from both human and mouse mast cell lines in a concentration dependent manner. Terfenadine, unluke cimenidine, revealed the ability to block histamine induced MCP-1 and IL-13 secretion. It implied that histamine induced secretion of IL-13 and MCP-1 from mast cells was conducted by the $\mathrm{H} 1$ receptor, and not $\mathrm{H} 2$ receptor. Moreover, U0126 and LY294002 diminished histamine induced secretion of IL-13 release from HMC-1 and P815 mast cells, indicating that reduction of IL-13 release by histamine occured through activation of PI3K/Akt [21] and Erk1/2/ MAPK signaling pathways [22]. However, U0126, and not LY294002, diminished histamine induced secretion of MCP-1 release, indicating that reduction of MCP-1 release by histamine occured through activation of Erk1/2/ MAPK signaling pathways.

Paralleling TLR3 upregulation, release of IL-13/MCP-1 was also increased by histamine via H1 receptor. Mast cells are known to produce IL-13 and MCP-1 following FceRI aggregation, or in response to other stimuli. It remains unknown whether there is any interaction between TLR3 and IL-13/MCP-1. Nonetheless, it has been reported that various TLR activators failed to induce any kind of significant IL-13 production [27] while they significantly released MCP1 [28] from mast cells. Therefore, the interaction between TLR3 and IL-13/MCP-1 needs to be further investigated.

It is known that poly(I:C) can activate TLR3 in human and murine cells [29]. Accordingly, we stimulated both HMC-1 and P815 cells with poly(I:C) after histamine challenge. We found that the release of MCP-1 and IL-13 by mast cells was more pronounced compared to any single stimulus (histamine or poly I:C). The observed effect indicated that histamine could synergize with TLR3 thus enhancing the release of inflammatory mediators from mast cell in addition to upregulating the expression of TLR3, which indicates that histamine may have a role in anti-infection immunity associated with TLR3. The mechanism underlying the interaction between these pass-ways has not been analyzed.

Histamine is an important mediator in the inflammatory and allergic diseases. It contributes to the progression of allergic inflammatory responses by enhancing the secretion of pro-inflammatory cytokines like IL-1 $\beta$, IL- 6 as well as chemokines such as IL- 8 and 


\section{Cellular Physiology Cell Physiol Biochem 2018;46:2401-2411

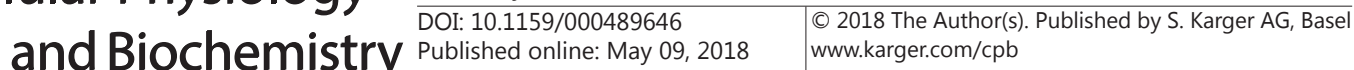

Xie et al.: Histamine Up-Regulates TLR3 Expression in Mcs

RANTES in inflammatory cells and local tissues [30,31]. In our study, we found that mast cell lines all express TLR3. It has been shown that histamine could induce upregulation of TLR3 expressed both in HMC-1 and P815 cell lines via H1 receptors. Histamine also induces the secretion of IL-13 and MCP-1 from both human and mouse mast cell lines in a concentration dependent manner, which can be enhanced by TLR3 ligands such as synthetic dsRNA analogue poly(I:C). We also demonstrated that the PI3K/Akt and Erk1/2/ MAPK signaling pathways are involved in histamine -mediated regulation of TLR3 expression and cytokines secretion. Accordingly, TLRs have an important role in innate immunity recognizing specific, nonself and conserved components shared by different pathogens. Our results imply there is a new mechanism for the histamine not only in allergic response, but also in anti-infection immunity.

\section{Disclosure Statement}

The authors declare no conflict of interest.

\section{References}

1 Galli SJ, Nakae S, Tsai M: Mast cells in the development of adaptive immune responses. Nat Immunol 2005;6:135-142.

-2 Morita H, Saito H, Matsumoto K, Nakae S: Regulatory roles of mast cells in immune responses. Semin Immunopathol 2016;38:623-629.

- G Gao Y, Xu B, Zhang P, He Y, Liang X, Liu J, Li J: TNF- $\alpha$ Regulates Mast Cell Functions by Inhibiting Cell Degranulation. Cell Physiol Biochem 2017;44:751-762.

-4 Zhang X, Yao H, Qian Q Li N, Jin W, Qian Y: Cerebral Mast Cells Participate In Postoperative Cognitive Dysfunction by Promoting Astrocyte Activation. Cell Physiol Biochem 2016;40:104-116.

-5 Daniela Carlos, Anderson Sá-Nunes, Lúcia de Paula: Histamine modulates mast cell degranulation through an indirect mechanism in a model IgE - mediated reaction. Eur J Immunol 2006;36:1494-1503.

6 Belon P, Cumps J, Ennis M, Mannaioni PF, Roberfroid M, Sainte-Laudy J, Wiegant FAC: Histamine dilutions modulate basophil activation. Inflamm Res 2004;53:181-188.

7 Jemima EA, Prema A, Thangam EB: Functional characterization of histamine H4 receptor on human mast cells. Mol Immunol 2014;62:19-28.

8 Sandig H, Bulfone-Paus S: TLR signaling in mast cells: common and unique features. Front Immunol. 2012;4:185.

-9 Yang H, Kong X, Wei J, Liu C, Song W, Zhang W, Wei W, He S: Cockroach allergen Per a 7 down-regulates expression of Toll-like receptor 9 and IL-12 release from P815 cells through PI3K and MAPK signaling pathways. Cell Physiol Biochem 2012;29:561-570.

10 Yang H, Wei J, Zhang H, Lin L, Zhang W, He S: Upregulation of Toll-like receptor (TLR) expression and release of cytokines from P815 mast cells by GM-CSF. BMC Cell Biol 2009;10:37.

11 Yang H, Wei J, Zhang H, Song W, Wei W, Zhang L, Qian K, He S: Upregulation of Toll-like Receptor (TLR) expression and release of cytokines from mast cells by IL-12. Cell Physiol Biochem 2010;26:337-346.

-12 Supajatura V, Ushio H, Nakao A, Okumura K, Ra C, Ogawa H: Protective roles of mast cells against enterobacterial infection are mediated by Toll-like receptor 4. J Immunol 2001;167:2250-2256.

13 Comer BS, Camoretti-Mercado B, Kogut PC, Halayko AJ, Solway J, Gerthoffer WT: MicroRNA-146a and microRNA-146b expression and anti-inflammatory function in human airway smooth muscle. Am J Physiol Lung Cell Mol Physiol 2014;307:L727-L734.

14 Ueta M, Uematsu S, Akira S, Kinoshita S: Toll-like receptor 3 enhances late-phase reaction of experimental allergic conjunctivitis. J Allergy Clin Immunol 2009;123:1187-1189.

15 Nakamura N, Tamagawa-Mineoka R, Ueta M, Kinoshita S, Katoh N: Toll-like receptor 3 increases allergic and irritant contact dermatitis. J Invest Dermatol 2015;135:411-417. 


\section{Cellular Physiology Cell Physiol Biochem 2018;46:2401-2411

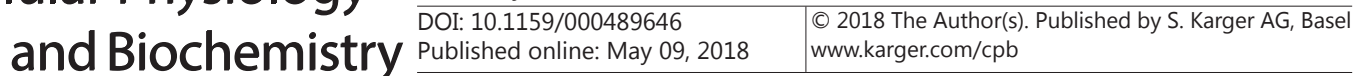 \\ Xie et al.: Histamine Up-Regulates TLR3 Expression in Mcs}

-16 Aldinucci A, Bonechi E, Manuelli C: Histamine Regulates Actin Cytoskeleton in Human Toll-like Receptor 4-activated Monocyte-derived Dendritic Cells Tuning CD4+ T Lymphocyte Response. J Biol Chem 2016;291:14803-14814.

17 Jang S, Park JS, Won YH, Yun SJ, Kim SJ: The Expression of Toll-Like Receptors (TLRs) in Cultured Human Skin Fibroblast is Modulated by Histamine. Chonnam Med J 2012;48:7-14.

18 Hou YF, Zhou YC, Zheng XX, Wang HY, Fu YL, Fang ZM, He SH: Modulation of expression and function of Tolllike receptor 3 in A549 and H292 cells by histamine. Mol Immunol 2006;43:1982-1992.

19 Talreja J, Kabir MH, B Filla M, Stechschulte DJ, Dileepan KN: Histamine induces Toll-like receptor 2 and 4 expression in endothelial cells and enhances sensitivity to Gram-positive and Gram-negative bacterial cell wall components. Immunology 2004;113:224-233.

20 Packard KA, Khan MM: Effects of histamine on Th1/Th2 cytokine balance. Int Immunopharmacol 2003;3:909-920.

-21 Lin H, Zheng C, Li J, Yang C, Hu L: Lentiviral shRNA against KCa3.1 inhibits allergic response in allergic rhinitis and suppresses mast cell activity via PI3K/AKT signaling pathway. Sci Rep 2015;5:13127.

-22 Kojima R, Ohno T, Iikura M, Niki T, Hirashima M, Iwaya K, Tsuda H, Nonoyama S, Matsuda A, Saito H, Matsumoto K, Nakae S: Galectin-9 enhances cytokine secretion,but suppresses survival and degranulation, in human mast cell line. PLoS One 2014;9:e86106.

-23 Arthur G, Bradding P: New Developments in Mast Cell Biology: Clinical Implications. Chest 2016;150:680693.

24 Zhang X, Wang Y, Dong H, Xu Y, Zhang S: Induction of Microglial Activation by Mediators Released from Mast Cells. . Cell Physiol Biochem 2016;38:1520-1531.

-25 McLeod JJ, Baker B, Ryan JJ: Mast cell production and response to IL-4 and IL-13. Cytokine 2015;75:57-61.

-26 Katsanos GS, Anogeianaki A, Orso C, Tetè S, Salini V, Antinolfi PL, Sabatino G: Mast cells and chemokines. J Biol Regul Homeost Agents 2008;22:145-151.

27 Matsushima H, Yamada N, Matsue H, Shimada S: TLR3-, TLR7-, and TLR9-mediated production of proinflammatory cytokines and chemokines from murine connective tissue type skin-derived mast cells but not from bone marrow-derived mast cells. J Immunol 2004;173:531-541.

28 Saluja R, Delin I, Nilsson GP, Adner M: FceR1-mediated mast cell reactivity is amplified through prolonged Toll-like receptor-ligand treatment. PLoS One. 2012;7:e43547.

29 Matsumoto M, Seya T: TLR3: interferon induction by double-stranded RNA including poly (I: C). Adv Drug Deliv Rev 2008;60:805-812.

-30 Jutel M, Blaser K, Akdis CA: Histamine in chronic allergic responses. J Investig Allergol Clin Immunol 2005;15:1-8.

-31 Jutel M, Akdis M, Akdis CA: Histamine, histamine receptors and their role in immune pathology. Clin Exp Allergy 2009;39:1786-1800. 